\title{
Effect of Menopause Duration and Biopsychosocial Factors on Quality of life of Women in Kediri District, East Java
}

\author{
Nunik Ike Yunia Sari'), Rita Benya Adriani²), Ambar Mudigdo 3) \\ 1) Masters Program in Public Heath, Sebelas Maret University, Surakarta \\ 2) Health Polytechnics Program, Ministry of Health, Surakarta \\ 3) Department of Anatomical Pathology, Faculty of Medicine, Sebelas Maret University
}

\begin{abstract}
Background: Menopause is defined as the point in time when menstrual cycles permanently cease due to the natural depletion of ovarian oocytes from aging. Studies have shown, menopause causes decrease in quality of life and a positive correlation between menopausal symptoms and quality of live. This study aimed to determine the effect of menopause duration and biopsychosocial factors on quality of life of women.

Subjects and Method: This study was an analytic study using cross-sectional design. The study was conducted in Bendo Community Health Center, Kediri District, East Java, from 8-31 March 2017. A sample was of 105 menopausal women was selected for this study by proportionate random sampling. The dependent variable was quality of life. Quality of life encompassed several constructs including physical, functional, emotional, social, and cognitive variables. The independent variables were duration of menopause, Body Mass Index (BMI), education, family support, and family income. The data were collected by pre-tested questionnaire, and analyzed by path analysis.

Results: Quality of life was affected by menopause duration $(b=2.19 ; \mathrm{SE}=0.38 ; \mathrm{p}<0.001)$, education $(b=6.72 ; \mathrm{SE}=1.72 ; \mathrm{p}<0.001)$, family support $(\mathrm{b}=0.42 ; \mathrm{SE}=0.17 ; \mathrm{p}=0.011), \mathrm{BMI}(\mathrm{b}=0.71$; $\mathrm{SE}=0.27 ; \mathrm{p}=0.010)$, and family income $(\mathrm{b}=0.13 ; \mathrm{SE}=1.60 ; \mathrm{p}=0.936)$. BMI was affected by education $(b=1.87 ; \mathrm{SE}=0.50 ; \mathrm{p}<0.001)$.

Conclusion: Quality of life is directly affected by menopause duration, education, family support, BMI, and family income. Quality of life is indirectly affected by education.
\end{abstract}

Keywords: menopause duration, biopsychosocial factors, quality of life, path analysis

\section{Correspondence:}

Nunik Ike Yunia Sari. Masters Program in Public Health, Sebelas Maret University, Surakarta. Email: nunikike@yahoo.com. Mobile: +6282257969278.

\section{LATAR BELAKANG}

$\overline{\text { Dalam setiap tahap kehidupan, wanita akan }}$ menghadapi perubahan mulaidarimasa menarche hingga pada tahap menopause. Menopause didefinisikan sebagai berhentinya menstruasi pada wanita selama dua belas bulan secara berturut-turut akibat penurunan kadar esterogen. Sebelum melalui masa menopause, wanita biasanya mengalami gejala klimakterik terlebih dahulu diantaranya gejala vasomotor, fisik, keluhan psikologis maupun seksual. Sebagian besar wanita menopause tidak menyadari akan perubahan-perubahan yang mereka alami ketika memasuki masa menopause (Seeta et al., 2015).

Menurut Proverawati dalam Apriyanti (2012), sidrom pre menopause dialami oleh banyak wanita hampir di seluruh dunia, sekitar 70-80\% wanita Eropa, 60\% di Amerika, 57\% di Malaysia, 18\% di Cina, dan 10\% di Jepang dan Indonesia. Berdasarkan data Survey Demografi Kesehatan Indonesia (SDKI) tahun 2013 menunjukkan bahwa proporsi wanita 30-49 tahun di Indonesia yang mengalami menopause meningkat 
Journal of Maternal and Child Health (2017), 2(2): 125-136

https://doi.org/10.26911/thejmch.2017.02.02.04

seiring dengan meningkatnya usia wanita. Seperti yang diduga persentase menopause meningkat dari $11 \%$ pada wanita umur $30-$ 34 tahun, menjadi $23 \%$ pada wanita umur 44-45; dan menjadi $44 \%$ pada wanita umur 48-49 tahun.

Berdasarkan penelitian yang telah dilakukan oleh Senba dan Matsuo et al., (2010) tentang Effects of a health education programon climacteric women didapatkan hasil bahwa $22.7 \%$ perempuan klimakterium tanpa mengalami gejala, $36.4 \%$ mengalami gejala yang sedang dan $36.4 \%$ mengalami gejala yang berat.

Hasil penelitian Trisetyaningsih(2016) tentang hubungan gejala menopause dengankualitas hidup perempuan klimakterik, didapatkan hasil bahwa $78.4 \%$ wanita klimakterium mengalami gejala ketidaknyamanan akibat nyeri otot dan persendian, 72.2\% wanita juga mengalami masalah seksual berupa perubahan gairah dan aktivitasseksual sertarasa kering di vagina. Gejala tersebut bila terus menerus dirasakan tentunya akan menurunkan kualitas hidup wanita menopause.

Seiring dengan meningkatnya usia harapan hidup wanita menjadi 70.43 tahun pada tahun 2014 dan 73.77 tahun di tahun 2025, maka dapat diprediksi bahwa mayoritas wanita akan mengalami gejala menopause lebih dari 30 tahun setelah melalui masa menopause dan menghabiskan sekitar sepertiga umur dari kehidupan mereka dengan keadaan kekurangan estero-gen yang berdampak pada berbagai masalah kesehatan yang mempengaruhi kualitas hidupnya (Bener and Anas, 2014).

Berbagai faktor biopsikososial berpengaruh pada kualitas hidup menopause diantaranya durasi menopause, BMI, dukungan keluarga, tingkat pendidikan dan pendapatan keluarga. Hasil penelitian yang dilakukan oleh Sudeshna and Aparajita (2012) didapatkan hasil bahwa wanita dengan durasi menopause kurang dari 5 tahun memiliki perbedaan signifikan dalam domain psikososial dan seksual. Berdasarkan variabel dukungan keluarga didapatkan hasil yang signifikan mengenai domain fisik dan psikologis.

Menurut penelitian yang dilakukan oleh Daley et al., (2007) didapatkan hasil bahwa efek BMI secara signifikan ditemukan untuksub-skala gejala vasomotor dan gejala somatik pada wanita dengan BMI yang tinggi. Menurut Kothiyal(2013) wanita yang memiliki pendapatan keluarga yang rendah cenderung memiliki pendidikan yang rendah, akses terhadap fasilitas pelayanan kesehatan yang sulit terjangkau, serta ketersediaan makanan yang bergizi yang berkaitan dengan keluhan yang dirasakan pada masa menopause (Kothiyal dan Monika, 2013)

Menurut Bener and Anas (2014), dampak yang dapat ditimbulkan pada saat wanita mengalamimenopause adalah resiko terjadinya penyakit tertentu yang berhubungan dengan penurunan hormon esterogen. Salah satunya adalah kematian akibat penyakit jantung iskemik dan stroke. Tanpa adanya intervensi lanjut pada wanita menopause, lebih dari $75 \%$ perempuan akan mengalami gejala sisa dari menopause yang meliputi sakit kepala, lekas marah, kelelahan, depresi, gangguan psikologis, konsentrasi buruk, disfungsi seksual, osteoporosis, dan pola umum penuaan pada setiap individu (Bener and Anas, 2014). Solusi yang dapat dilakukan untuk mencegah terjadinya dampak yang berkelanjutan pada menopause adalah dengan melakukan penyuluhan kesehatan terkait pola hidup sehat, peningkatan aktivitas fisik, konsumsi makanan kaya fitoesterogen serta penggunaan hormone replacement therapy (HRT).

Jumlah wanita menopause di Jawa Timur pada tahun 2010 mengalami peningkatan yang cukup tinggi, yaitu menjadi 
69.65\%, namun hanya $39.53 \%$ yang telah mendapatkan layanan kesehatan (Depkes RI, 2010). Berdasarkan hasil sensus penduduk 2013 jumlah penduduk wanita yang berusia $\geq 45$ tahun di Kabupaten Kediri sebanyak 763,808 jiwa (BPS, 2013). Kabupaten Kediri memiliki poyandu lansia sebanyak 514 posyandu. Tingginya jumlah Posyandu Lansia di Kabupaten Kediri tersebut tidak diimbangi dengan pencapaian target terhadap pelayanan kesehatan lansia di Kabupaten Kediri yang masih di bawah target yaitu 63\% dari target 65\% (Profil Kesehatan Kabupaten Kediri, 2014). Dari studi pendahuluan yang telah dilakukan di wilayah kerja puskesmas Bendo, Kabupaten Kediri didapatkan hasil bahwa dari 10 wanita menopause, 70\% diantaranya mengalami keluhan dalam domain fisik, yaitu nyeri otot dan sendi yang mengganggu dalam menjalani aktivitas sehari-hari.

Tujuan penelitian ini adalah untuk menganalisis pengaruh durasi menopause dan faktor biopsikososial terhadap kualitas hidup wanita menopause di wilayah Puskesmas Bendo Kabupaten Kediri, Jawa Timur.

\section{SUBJEK DAN METODE \\ 1. Desain Penelitian \\ Penelitian ini merupakan analitik observa- sional dengan pendekatan dilakukan secara cross sectional yaitu suatu penelitian untuk mempelajari korelasi antara faktor-faktor risiko dengan efek yang dilakukan pada suatu saat (point time approach). Peneliti- an ini dilakukan untuk mempelajari faktor- faktor yang berhubungan dengan kualitas hidup menopause. Penelitian ini dilaksana- kan di beberapa desa di wilayah kerja pus- kesmas Bendo, Kabupaten Kediri, Jawa Timur pada tanggal 8-31Maret 2017.}

\section{Populasi dan sampel}

Populasi dalam penelitian ini adalah seluruh wanita menopause di wilayah kerja puskesmas Bendo. Sampel dalam penelitian kuantitatif ini adalah sebagian wanita menopause di wilayah kerja puskesmas Bendo sebesar 102 subjek penelitian.

\section{Teknik sampling}

Teknik sampling yang digunakan dalam penelitian ini yaitu proportionate random sampling. Teknik ini digunakan bila populasinya mempunyai anggota atau unsur yang tidak homogen dan dalam jumlah yang besar. (Sugiyono, 2015). Teknik pengambilan sampel secara proporsi dilakukan dengan mengambil subjek dari setiap wilayah ditentukan seimbang dengan banyaknya subjek dalam masing-masing wilayah, dan selanjutnya diambil sampel menggunakan teknik simple random sampling.

Subjek penelitian dipilih berdasarkan kriteria inklusi dan eksklusi. Kriteria eksklusi meliputi wanita dengan terapi Hormone Replacement Therapy (HRT), pengobatan kemoterapi serta pernah melakukan operasi hysterectomy maupun ovarectomy. Sampel diambil dari masing-masing desa sebesar 18-22 subjek penelitian.

\section{Variabel penelitian}

Terdapat enam variabel dalam penelitian ini yang terdiri dari variabel eksogen yang meliputi durasi menopause, dukungan keluarga, tingkat pendidikan, pendapatan keluarga dan variabel endogen yang meliputi BMI dan kualitas hidup menopause.

\section{Definisi operasional}

Definisi operasional variabel durasi menopause adalah rentang waktu mulainya menopause dialami sampai penelitian dilakukan; BMI adalah perbandingan dari berat badan terhadap tinggi badan pada wanita menopause; dukungan keluarga adalah dukungan dari suami, anak/keluarga terdekat dalam bentuk membantu atau memberikan perhatian kepada subjek penelitian; tingkat pendidikan adalah jenjang pendidikan formal tertinggi yang telah diselesaikan oleh subjek penelitian; pendapatan keluarga adalah penghasilan yang 
Journal of Maternal and Child Health (2017), 2(2): 125-136

https://doi.org/10.26911/thejmch.2017.02.02.04

diperoleh suami dan istri dari berbagai kegiatan ekonomi dalam satu bulan; dan kualitas hidup menopause adalah persepsi wanita menopause atas kesehatannya dengan menilai besarnya keluhan yang berhubungan dengan keberfungsian dirinya dalam menjalani kehidupan.

Pengumpulan data menggunakan kuesioner. Variabel yang diukur yakni dukungan keluarga, meliputi dukungan informasi, finansial, emosional, dan penghargaan. Instrumen yang diuji reliabilitasnya adalah kuesioner dukungan keluarga. Berdasarkan hasil uji reliabilitas korelasi item-total didapatkan bahwa pada pengukuran variabel dukungan keluarga $r$ hitung $\geq 0.47$, serta Cronbach's Alpha $\geq 0.72$, sehingga semua butir pertanyaan dinyatakan reliabel.

\section{Analisa data}

Analisis data dalam penelitian ini menggunakan analisis univariat dan multivariat. Analisis multivariat menggunakan analisis jalur. Menurut Murti (2014) langkahlangkah dalam melakukan analisis jalur, yaitu sebagai berikut:

a. Spesifikasi model,

Spesifikasi model digambarkan hubungan antara variable-variabel yang akan diteliti. Variabel yang diteliti dibedakan menurut variable endogen dan eksogen.

b. Identifikasi model

Tahap ini dilakukan identifikasi jumlah variabel yang terukur, jumlah variabel endogen, variabel eksogen, dan parameter yang akan diestimasi. Tahap ini dihitung degree of freedom (df) yang menunjukkan analisis jalur bisa dilakukan. Analisis jalur bisa dilakukan apabila $\mathrm{df} \geq 0$, dalam penelitian ini didapatkan hasil degree of freedom (df) sebesar 3 dikatakan over identified sehingga analisis jalur dapat dilakukan c. Kesesuaian model

Model analisis jalur yang dibuat oleh peneliti berdasarkan teori dicek/ dites kesesuaiannya dengan model hubungan variabel yang terbaik menurut komputer (SPSS) disebut model saturasi, yang dibuat berdasarkan data sampel yang dikumpulkan peneliti.

d. Estimasi parameter

Hubungan sebab akibat variabel ditunjukan oleh koefisien regresi (b), baik yang belum terstandarisasi (unstandardized) maupun yang sudah distandarisasi (standardized). Koefisien regresi yang belum terstandarisasi menunjukkan hubungan variabel independen dan dependen dalam unit pengukuran yang asli.

e. Respesifikasi model

Jika model yang dibuat peneliti tidak sesuai dengan data sampel sebagaimana ditunjukkan oleh model saturasi dan juga terdapat koefisien regresi yang bernilai sangat kecil mendekati nol serta secara statistik tidak signifikan, maka perlu dibuat ulang model analisis jalur sehingga diperoleh model yang sesuai dengan data sampel.

\section{HASIL}

Dimensi karakteristik dari wanita menopause dilihat menurut usia dan pekerjaan. Tabel 1 menunjukkan bahwa dari 102 subjek penelitian didapatkan $83.3 \%$ berusia 51-59 tahun; 67.7\% sebagai IRT islam.

Hasil statistik deskriptif data kontinu yang berupa durasi menopause, BMI, dukungan keluarga, tingkat pendidikan, pendapatan keluarga dan kualitas hidup menopause dapat dilihat pada Tabel 2.

Tabel 3 menunjukkan bahwa masingmasing variabel memiliki keberagaman data yang relatif kecil. Mean menggambarkan nilai rata-rata, sedangkan nilai standard deviation (SD) menggambarkan seberapa jauh bervariasinya data. SD yang kecil merupakan indikasi bahwa data representtatif. 
Tabel 1. Karakteristik subjek penelitian

\begin{tabular}{llcc}
\hline Karakteristik & \multicolumn{1}{c}{ Kriteria } & n & \% \\
\hline Usia & 45-50 tahun & 5 & 3.4 \\
& 51-59 tahun & 85 & 50.8 \\
Pekerjaan & 60 tahun & 12 & 45.8 \\
& IRT & 69 & 67.7 \\
& Swasta & 7 & 6.9 \\
& Wiraswasta & 23 & 22.5 \\
& PNS & 3 & 2.9 \\
\hline
\end{tabular}

Tabel 2. Analisis univariat variabel penelitian

\begin{tabular}{lccccc}
\hline Variabel & n & Min. & Maks. & Mean & SD \\
\hline Durasi menopause (tahun) & 102 & 1 & 9 & 5.16 & 1.99 \\
BMI $\left(\mathrm{kg} / \mathrm{m}^{2}\right)$ & 102 & 17 & 32 & 23.22 & 2.69 \\
Dukungan keluarga & 102 & 17 & 37 & 28.08 & 4.32 \\
$\begin{array}{l}\text { Pendapatan keluarga per bulan } \\
\text { (rupiah) }\end{array}$ & 102 & 750,000 & $2,500,000$ & $1,253,431.37$ & $374,645.69$ \\
Kualitas hidup menopause & 102 & 7 & 56 & 23.75 & 10.3 \\
\hline
\end{tabular}

Tabel 3. Analisis bivariat pengaruh durasi menopause dan faktor biopsikososial terhadap kualitas hidup menopause

\begin{tabular}{lcc}
\hline Variabel Independen & $\mathbf{r}$ & $\mathbf{p}$ \\
\hline Durasi menopause (tahun) & 2.19 & $<0.001$ \\
BMI $\left(\mathrm{kg} / \mathrm{m}^{2}\right)$ & 0.71 & 0.14 \\
Dukungan keluarga & 0.42 & 0.16 \\
Tingkat pendidikan terakhir & 6.26 & $<0.001$ \\
Pendapatan keluarga per bulan (rupiah) & 0.13 & 0.938 \\
\hline
\end{tabular}

Tabel 3 menunjukkan bahwa durasi menopause $(\mathrm{r}=2.19, \mathrm{p}<0.001)$, BMI $(\mathrm{r}=0.71$, $\mathrm{p}=0.14)$, dukungan keluarga $(\mathrm{r}=0.42, \mathrm{p}=$ $0.16)$, tingkat pendidikan $(\mathrm{r}=6.26, \mathrm{p}<0.001)$, pen-dapatan keluarga $(\mathrm{r}=0.13, \mathrm{p}=0.938)$

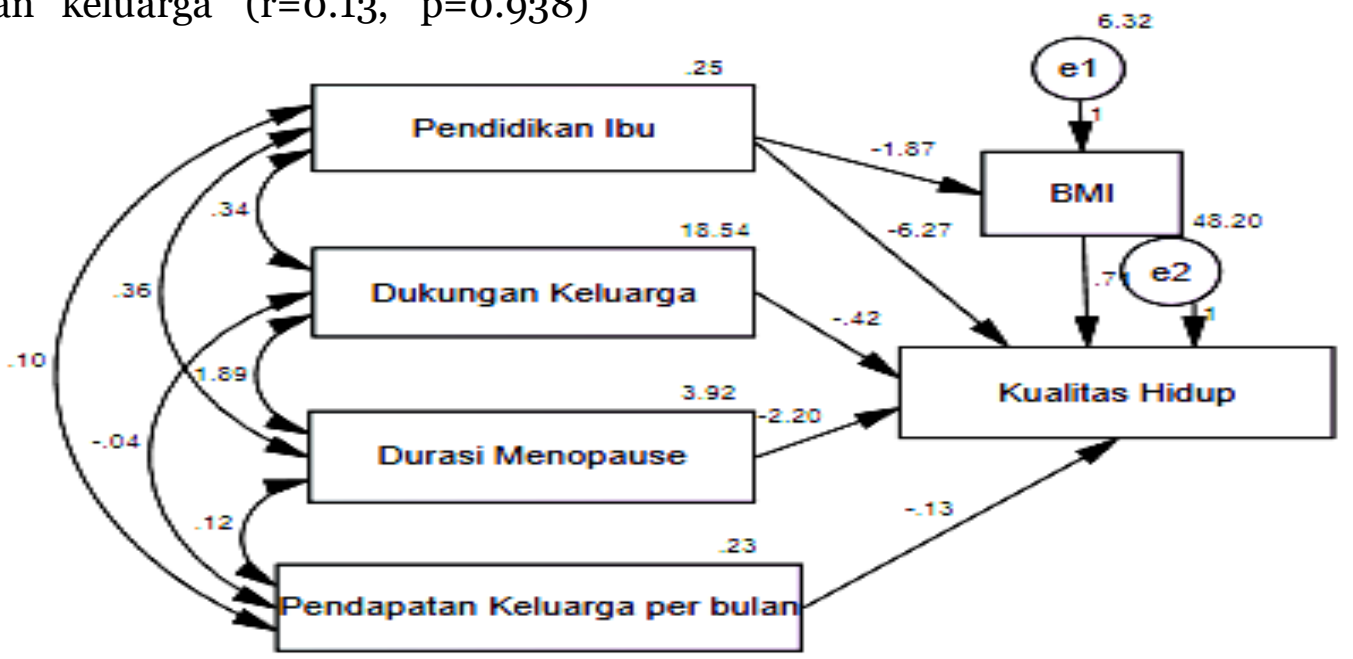

\section{Gambar 1. Model struktural analisis jalur}

Gambar 1 menunjukkan model struktural setelah dilakukan estimasi menggunakan IBM SPSS AMOS 22, sehingga didapatkan nilai seperti pada gambar tersebut. Indi- 
Journal of Maternal and Child Health (2017), 2(2): 125-136

https://doi.org/10.26911/thejmch.2017.02.02.04

kator yang menunjukan kesesuaian model analisis jalur yaitu seperti pada Tabel 5 juga menunjukan adanya goodness of fit measure (pengukuran kecocokan model) didapatkan bahwa hasil fit index (indeks kecocokan) CMIN sebesar 2.57 dengan $\mathrm{p}=0.463$
$>0.05 ; \mathrm{NFI}=0.98 \geq 0.90 ; \mathrm{CFI} 1.00 \geq 0.95$; RMSEA $=0.00 \leq 0.08$ yang berarti model empirik tersebut memenuhi kriteria yang ditentukan dan dinyatakan sesuai dengan data empirik.

Tabel 4. Hasil analisis jalur

\begin{tabular}{|c|c|c|c|c|c|c|}
\hline \multirow{2}{*}{\multicolumn{2}{|c|}{$\begin{array}{c}\text { Variabel Endogen } \\
\text { Pengaruh Langsung }\end{array}$}} & Variabel Eksogen & $\mathbf{b}^{*}$ & SE & $\mathbf{p}$ & $\beta^{* *}$ \\
\hline & & & & & & \\
\hline Kualitas hidup & $\leftarrow$ & Durasi Menopause (tahun) & 2.19 & 0.38 & $<0.001$ & 0.42 \\
\hline Kualitas hidup & $\leftarrow$ & Dukungan keluarga & 0.42 & 0.17 & 0.011 & 0.18 \\
\hline Kualitas hidup & $\leftarrow$ & Pendapatan keluarga (rupiah) & 0.13 & 1.60 & 0.936 & 0.01 \\
\hline Kualitas hidup & $\leftarrow$ & Tingkat pendidikan & 6.27 & 1.72 & $<0.001$ & 0.30 \\
\hline Kualitas hidup & $\leftarrow$ & $\mathrm{BMI}\left(\mathrm{kg} / \mathrm{m}^{2}\right)$ & 0.71 & 0.27 & 0.010 & 0.18 \\
\hline \multicolumn{7}{|c|}{ Pengaruh Tidak Langsung } \\
\hline BMI & $\leftarrow$ & Tingkat pendidikan & 1.87 & 0.50 & $<0.001$ & 0.35 \\
\hline \multicolumn{7}{|l|}{ Model Fit } \\
\hline $\mathrm{CMIN}=1.94$ & \multicolumn{6}{|c|}{$\mathrm{p}=0.59(>0.05)$} \\
\hline$=0.99$ & \multirow{2}{*}{\multicolumn{6}{|c|}{$\begin{array}{l}(\geq 0.90) \\
(\geq 0.90)\end{array}$}} \\
\hline$=0.99$ & \multirow{2}{*}{\multicolumn{6}{|c|}{$\begin{array}{l}(\geq 0.90) \\
(\geq 0.95)\end{array}$}} \\
\hline$=1.00$ & & \multicolumn{5}{|c|}{$(\geq 0.95)$} \\
\hline RMSEA $=0.00$ & \multicolumn{6}{|c|}{$(\leq 0.08)$} \\
\hline
\end{tabular}

Melalui Tabel 4 dapat diketahui bahwa kualitas hidup menopause dipengaruhi secara langsung oleh durasi menopause, dukungan keluarga, dan pendapatan keluarga.

Setiap peningkatan satu unit durasi menopause lama akan meningkatkan kualitas hidup menopause sebesar 2.19 unit $(\mathrm{b}=2.19 ; \mathrm{SE}=0.38 ;<0.001)$.

Setiap peningkatan satu unit dukungan keluarga yang mendukung akan meningkatkan kualitas hidup menopause sebesar 0.42 unit $(b=0.42 ; \quad \mathrm{SE}=0.17 ; \mathrm{p}=$ 0.011).

Setiap peningkatan satu unit pendapatan keluarga yang tinggi akan meningkatkan kualitas hidup menopause sebesar 0.13 unit $(b=0.13 ; \mathrm{SE}=1.60 ; \mathrm{p}=0.936)$.

Setiap peningkatan satu unit tingkat pendidikan yang tinggi akan meningkatkan kualitas hidup menopause sebesar 6.72 unit $(b=6.72 ; \mathrm{SE}=1.72 ; \mathrm{p}<0.001)$.
BMI dipengaruhi oleh tingkat pendidikan. Setiap peningkatan satu unit tingkat pendidikan tinggi akan meningkatkan BMI sebesar 1.87 unit $(b=1.87 ; \mathrm{SE}=0.50 ; \mathrm{p}<$ 0.001).

Setiap peningkatan satu unit BMI normal akan meningkatkan kualitas hidup menopause sebesar 0.71 unit $(b=0.71 ; \mathrm{SE}=$ $0.27 ; \mathrm{p}=0.010$ ).

\section{PEMBAHASAN}

\section{Pengaruh durasi menopause ter-} hadap kualitas hidup menopause

Terdapat pengaruh positif durasi menopause terhadap kualitas hidup menopause dan secara statistik signifikan. Penelitian ini sejalan dengan penelitian yang dilakukan oleh Sudeshna and Aparajita (2012) yang menyebutkan bahwa durasi menopause kurang dari 5 tahun memiliki perbedaan signifikan dalam domain psikososial dan seksual. Secara garis besar masa 
awal menopause merupakan masa adaptasi wanita dalam menghadapi perubahan terkait dengan penurunan hormon esterogen yang berdampak pada seksualitasnya, selain itu adanya berbagai keluhan di awal masa menopause membuat wanita merasa terbebani dengan berbagai ketidaknyamanan yang dihadapinya

Memasuki masa klimakterium terjadi penurunan produksi estrogen dan kenaikan hormon gonadotropin. Kekurangan estrogen menyebabkan pengeluaran $\beta$-endorfin berkurang, sehingga ambang sakit juga berkurang yang menyebabkan wanita menopause sering mengeluh sakit pinggang atau mengeluh nyeri di daerah kemaluan, tulang, dan otot (Baziad, 2003).

Selain perubahan fisik, pada masa menopause terjadi perubahan steroid seks yang sangat berperan terhadap fungsi susunan saraf pusat, terutama terhadap perilaku, suasana hati, serta fungsi kognitif dan sensorik seseorang. Akibat kekurangan hormon estrogen pada wanita paska menopause, timbulah keluhan seperti mudah tersinggung, cepat marah, dan rasa tertekan (Baziad, 2003). Penyebab depresi diduga akibat berkurangnya aktivitas serotonin di otak. Estrogen menghambat aktivitas enzim monoamine oksidase (MAO). Enzim ini mengakibatkan serotonin dan noradrenalin menjadi tidak aktif (Baziad, 2003).

Selain depresi, gangguan tidur merupakan keluhan paling banyak dikeluhkan wanita menopause. Kurang nyenyak tidur pada malam hari menurunkan kualitas hidup wanita tersebut. Estrogen memiliki efek terhadap kualitas tidur. Reseptor estrogen telah ditemukan di otak yang mengatur tidur. (Baziad, 2003).

Perubahan lain yang tidak kalah pentingnya, dan sering menjadi masalah utama adalah menurunnya dorongan seksual. Hal ini disebabkan pada masa menopause kemampaun organ-organ seksual perempuan mengalami kemunduran. Kebanyakan pakar seksologi berpendapat bahwa sebenarnya bukan faktor fisik yang menjadi penyebab perempuan menopouse tidak mau berhubungan seks, masalah utamanya adalah faktor psikis. Ketika menopouse, perempuan mempunyai rasa takut, gelisah dan tidak percaya diri (Hawari, 2013).

Berdasarkan pemaparan di atas dapat disimpulkan bahwa durasi menopause $\leq 5$ tahun memiliki kualitas hidup yang buruk pada domain fisik, domain psikososial, dan domain seksual. Wanita pada tahapan menopause membutuhkan intervensi lanjutan yakni pemberian KIE tentang perubahan fisik, psikologis, vasomotor dan seksual selama menopause serta bagaimana cara mengalihkan perhatian dari keluhan yang dirasakan yaitu dengan peningkatan dukungan keluarga terutama dukungan suami untuk meningkatkan rasa percaya diri dalam menghadapi perubahan yang dialaminya serta mengurangi stress dengan melakukan hal yang bersifat rekreatif. Selain dukungan, mereka juga membutuhkan. KIE tentang istirahat cukup dan peningkatan aktivitas fisik yang merupakan salah satu langkah untuk meminimalisir keluhan fisiknya.

\section{Pengaruh BMI terhadap kualitas hidup menopause}

Terdapat pengaruh positif BMI terhadap kualitas hidup menopause dan secara statistik signifikan. Penelitian ini sejalan dengan penelitian yang dilakukan Daley et al., (2007) tentang efek aktivitas fisik dan BMI terhadap kualitas hidup menopause di-dapatkan hasil bahwa efek BMI secara signifikan ditemukan untuk sub-skala gejala vasomotor dan gejala somatik daripada wanita dengan BMI normal. Wanita dengan BMI yang tinggi memiliki risiko lebih tinggi terhadap kejadian hot flushes, inkontinensia urin dan nyeri sendi daripada wanita 
Journal of Maternal and Child Health (2017), 2(2): 125-136

https://doi.org/10.26911/thejmch.2017.02.02.04

dengan BMI yang rendah (Kothiyal dan Monika, 2013).

Penyebab terjadinya keluhan vasomotorik umumnya pada saat kadar estrogen mulai menurun. Semburan panas dirasakan mulai dari daerah dada dan menjalar ke leher dan ke kepala yang akan diikuti dengan rasa sakit kepala, perasaan kurang nyaman, dan peningkatan frekuensi nadi. Hal ini disebabkan oleh peningkatan pengeluaran hormon adrenalin dan neurotensin oleh tubuh wanita tersebut. Selain itu, terjadi pula penurunan sekresi hormon noradrenalin sehingga terjadi vasodilatasi pembuluh darah kulit, temperatur kulit sedikit meningkat dan timbul perasaan panas. Akibat vasodilatasi dan keluarnya keringat, terjadi pengeluaran panas tubuh sehingga kadang-kadang wanita merasa kedinginan. Gejolak panas tidak hanya mengganggu pekerjaan dan aktivitas sehari-hari, tetapi juga dapat menyebabkan gangguan tidur, cepat lelah, dan cepat tersinggung atau kurang sabar. Banyak wanita melaporkan sulit konsentrasi dan emosional labil selama transisi menopause (Baziad, 2003).

Selain domain vasomotor, domain fisik juga merupakan keluhan yang paling banyak dialami menopause. Hal tersebut sesuai dengan hasil penelitian yang menunjukkan bahwa perubahan gejala atau keluhan yang dirasakan oleh menopause dikaitkan dengan penumpukan lemak pusat dan lemak intra-abdominal khususnya yang berhubungan dengan sindrom metabolik (Yanuarti, 2014). Kegemukan (obesitas) adalah faktor risiko terkuat untuk terjadinya osteoartritis. Efek obesitas terhadap perkembangan osteo-artritis yakni melalui peningkatan beban pada sendi-sendi penopang berat badan. Tiga hingga enam kali berat badan dibebankan pada sendi lutut pada saat tubuh bertumpu pada satu kaki. Peningkatan berat badan akan melipat gandakan beban sendi lutut saat berjalan.
Obesitas tidak hanya mengawali timbulnya penyakit osteoartritis, tetapi juga merupakan akibat lanjut dari inaktivitas para penderita osteoartritis (Yanuarti, 2014).

Berdasarkan pemaparan di atas dapat disimpulkan bahwa BMI obesitas memiliki kualitas hidup yang buruk pada domain fisik, domain psikososial, dan domain vasomotor. Pada tahapan ini wanita menopause membutuhkan intervensi lanjutan yakni pemberian KIE tentang pola nutrisi (diet) seimbang dan gaya hidup sehat yang meliputi peningkatan aktivitas fisik merupakan salah satu upaya untuk mempertahankan BMI normal dan menurunkan berat badan pada wanita menopause. BMI normal akan meminimalisir terjadinya keluhan-keluhan pada menopause yang mempengaruhi kualitas hidupnya.

\section{Pengaruh dukungan keluarga terhadap kualitas hidup menopause}

Terdapat pengaruh positif dukungan keluarga terhadap kualitas hidup menopause dan secara statistik signifikan. Penelitian ini sejalan dengan hasil penelitian yang dilakukan oleh Sudeshna dan Aparajita (2012) didapatkan hasil bahwa wanita menopause yang tidak mendapatkan dukungan keluarga mengalami keluhan pada domain fisik dan psikologis. Dukungan keluarga memiliki perbedaan signifikan dalam domain fisik dan psikososial. Dukungan suami dan keluarga akan mempengaruhi kesejahteraan psikologisnya yang ditandai dengan rasa nyaman dan bahagia yang tentunya juga akan berdampak pada berkurangnya keluhan akan gejala vasomotor, fisik dan seksual yang dialaminya.

Masa menopause dengan berbagai perubahan yang dialaminya tentunya akan menimbulkan stress yang dapat mengakibatkan berbagai jenis keluhan. Stres dapat meningkatkan penge-luaran $\beta$-endorfin, dan zat ini memicu pengeluaran ACTH. $\beta$-endorfin dan ACTH berasal dari precur- 
sor yang sama, yaitu prepiomelanocortin (POMC), yang banyak ditemukan di dalam nukleus arkuatus. POMC ini merupakan suatu peptida yang membentuk $\beta$-endorfin di hipotalamus dan ACTH di hipofisis anterior (Baziad, 2003). Meningkatnya kadar $\beta$-endorfin dalam tubuh tentuya akan semakin menambah terjadinya keluhan terutama pada domain psikososial.

Hasil penelitian menunjukkan bahwa sebagian besar wanita menopause yang memiliki kualitas hidup buruk tidak mendapatkan dukungan keluarga dari aspek penghargaan (74\%), emosional (70\%) dan informasi (59\%). Dukungan penghargaan dapat diperoleh dengan memberikan penghargaan positif kepada orang lain yang sedang stress, dorongan atau persetujuan terhadap ide ataupun perasaan individu. Dukungan ini dapat menyebabkan individu yang menerima dukungan membangun rasa menghargai dirinya, percaya diri dan merasa bernilai (Lubis dan Hasnida, 2009). Dukungan jenis ini akan sangat berguna ketika individu mengalami stress terkait dengan keluhan yang dialami pada masa menopause.

Dukungan emosional dapat diperoleh dari pemberian ungkapan empati, kepedulian dan perhatian terhadap orang yang bersangkutan misalnya reward, pemberian semangat serta pujian terhadap hal yang sudah dilalui (Lubis dan Hasnida, 2009).

Pemberian dukungan emosional wanita menopause yang mengalami keluhan terkait menopause akan merasa tenang karena adanya empati dan perhatian dari keluarga, sehingga keluhan tersebut tidak begitu dirasakan dampaknya terhadap kualitas hidup wanita tersebut. Selain dukungan penghargaan dan emosional, dukungan informasi juga sangat diperlukan oleh menopause.

Berdasarkan pemaparan di atas dapat disimpulkan bahwa wanita menopause yang tidak mendapatkan dukungan keluarga memiliki kualitas hidup yang buruk pada domain fisik, domain psikososial, dan domain seksual. Peningkatan pemberian KIE terhadap keluarga dan masyarakat tentang pentingnya dukungan keluarga terhadap kualitas hidup menopause merupakan salah satu upaya untuk meningkatkan rasa percaya diri wanita menopause dalam menghadapi berbagai keluhan yang dirasakan. Pengertian, penerimaan dan dukungan dari suami, keluarga dan lingkungan sangat besar artinya bagi perempuan yang menjalani menopouse. Perhatian yang diperoleh akan membuatnya merasa berharga.

\section{Pengaruh tingkat pendidikan ter- hadap kualitas hidup menopause}

Terdapat pengaruh positif tingkat pendidikan terhadap kualitas hidup menopause secara signifikan yaitu secara tidak langsung melalui BMI. Wanita dengan pendidikan tinggi akan lebih memahami bagaimana cara untuk mempertahankan status gizi mereka. Sebaliknya, perkembangan kognitif, intelektual, serta mental seseorang yang berpendidikan rendah di-batasi oleh keterbatasan informasi serta kemampuan yang dimilikinya. Maka orang yang berpendidikan tinggi lebih mudah menerima dan memahami informasi, sehingga lebih mampu menentukan sikap yang tepat bagi dalam mempertahankan status kesehatannya terutama dalam hal status gizi dibandingkan dengan seseorang yang tingkat pendidikannya rendah.

Selain pengaruh secara tidak langsung, tingkat pendidikan juga berpengaruh secara langsung terhadap kualitas hidup menopause dan secara statistik signifikan. Penelitian ini sejalan dengan penelitian yang dilakukan oleh Eugnia et al., (2014) yang menyebutkan bahwa pendidikan berhubungan dengan kualitas hidup wanita menopause. 
Journal of Maternal and Child Health (2017), 2(2): 125-136

https://doi.org/10.26911/thejmch.2017.02.02.04

Wanita yang memiliki pendidikan tinggi berhubungan baik dengan kemudahan mengakses layanan kesehatan, memperoleh pekerjaan dan pendapatan yang lebih tinggi (Kalarhoudi et al., 2011), memiliki karakter mudah beradaptasi dan mengendalikan situasi yang berdampak pada tingkat stress dan kemampuan untuk bersikap positif dalam menghadapi penuaan dan menopause sehingga kualitas hidupnya lebih baik daripada yang berpendidikan rendah dan belum mendapatkan informasi tentang menopause. Selain itu, pendidikan juga mengajarkan individu dan masyarakat untuk dapat berpikir secara objektif, yang mana akan membangun kemampuan untuk menilai apakah kebudayaan masyarakat dapat memenuhi kebutuhan sesuai kondisinya (Eugenia et al., 2014). Kemudahan untuk memilih dan mengatur asupan makanan apa saja yang akan dikonsumsi demi menunjang derajat kesehatannya.

Berdasarkan pemaparan di atas dapat disimpulkan bahwa wanita menopause yang berpendidikan rendah memiliki kualitas hidup yang buruk. Peningkatan pemberian KIE dan evaluasi secara rutin di setiap kegiatan posyandu mengenai pola nutrisi (diet) seimbang, gaya hidup sehat, dan cara mengatasi keluhan yang dialami selama menopause merupakan salah satu upaya untuk meningkatkan pengetahuan menopause terhadap cara mempertahankan dan memperbaiki kualitas hidupnya. Riwayat pendidikan yang rendah dan faktor usia merupakan suatu tantangan untuk memberikan intervensi lebih lanjut untuk meningkatkan pengetahuan dan mengubah gaya hidup terkait kualitas hidup menopause.

\section{Pengaruh pendapatan keluarga terhadap kualitas hidup menopause}

Terdapat hubungan positif antara budaya dengan perilaku perawatan alat reproduksi dan secara statistik tidak signifikan.
Menurut penelitian yang dilakukan oleh Kalarhoudi et al., (2011) didapatkan hasil bahwa terdapat hubungan antara pendapatan dengan kualitas hidup wanita menopause. Wanita yang memiliki pendapatan keluarga yang rendah cenderung memiliki pendidikan yang rendah, akses terhadap fasilitas pelayanan kesehatan yang sulit terjangkau, serta ketersediaan makanan yang bergizi yang berkaitan dengan faktor resiko timbulnya masalah kesehatan yang berkaitan dengan keluhan yang dirasakan pada masa menopause (Kothiyal dan Monika, 2013).

Penelitian ini menunjukkan pengaruh pendapatan keluarga terhadap kualitas hidup yang tidak signifikan. Hal ini dikarenakan kualitas hidup yang baik tidak hanya dipengaruhi oleh tingkat pendapatan saja, namun juga dipegaruhi oleh durasi menopause, BMI, dukungan keluarga, dan tingkat pendidikan. Meskipun pendapatan keluarga rendah, namun jika mereka cukup puas dan terbiasa dengan nutrisi yang dikonsumsi serta akses pelayanan kesehatan dan transportasi yang harus dijalani dapat membuat wanita menopause merasa keluhan yang dialami tidak begitu berpengaruh terhadap kualitas hidupnya. Hal tersebut sejalan dengan penelitian yang dilakukan oleh Tamai (2006) yang menyebutkan bahwa dari 100 subjek penelitian didapatkan $64 \%$ wanita menopause dengan pendapatan rendah. Mereka mengakui bahwa mereka cukup puas terhadap tempat tinggal, akses pelayanan kesehatan, dan transportasi yang harus dijalani. Hal tersebutlah yang menimbulkan tidak ditemukannya perbedaan kualitas hidup menurut pekerjaan dan pendapatan.

Berdasarkan pemaparan di atas dapat disimpulkan bahwa wanita menopause yang memiliki pendapatan yang rendah memiliki kualitas hidup yang baik pada domain fisik, domain psikososial, dan 
domain seksual. Peningkatan pemberian KIE dan evaluasi secara rutin di setiap kegiatan posyandu mengenai pola nutrisi (diet) seimbang, gaya hidup sehat, dan cara mengatasi keluhan yang dialami selama menopause merupakan salah satu upaya untuk meningkatkan pengetahuan menopause terhadap cara mempertahankan dan memperbaiki kualitas hidupnya. Intervensi yang dilakukan secara berkesinambungan dapat meningkatkan kualitas hidup wanita menopause.

Berdasarkan hasil penelitian ini dapat disimpulkan bahwa hidup menopause dipengaruhi oleh durasi menopause, BMI, dukungan keluarga, tingkat pendidikan, dan pendapatan keluarga. BMI dipengaruhi oleh tingkat pendidikan.

\section{DAFTAR PUSTAKA}

Apriyanti, E, Sumantri, Arum S (2012). Attitudes of Klimakterium's Women in Dealing Menopause Period at Jimus Village Polanharjo District Klaten Regency. Jurnal Ilmu Kesehatan, 4(2).

Baziad A (2003). Menopause dan Andropause. Cetakan Pertama. Jakarta: Yayasan Bina Pustaka Sarwono Prawiraharjo.

Bener A, Anas F (2014). Measurementspecific quality-of-life satisfaction during premenopause, perimenopause and postmenopause in Arabian Qatari women. Journal of Mid-life Health. 5(3).

BPS Provinsi Jawa Timur (2015). Jawa Timur dalam Angka 2015. Surabaya: BPS Provinsi Jawa Timur. ISSN: 0215 $-2193$.

Daley A, Christine M, Helen S, Richard M, Sue W, Nanette M (2007). Exercise participation, body mass index, and health-related quality of life in women of menopausal age. British Journal of General Practice, February 2007

Eugenia D, Eleni T, Anna K, Georgia F, John K, Martha K, Ourania G (2014). Sociodemographic Characteristics and Quality-of-life of Greek Meno-pausal Women treated with Hormone Therapy. Health Science Journal, 8(3).

Hawari D (2013). Manajemen Stres Cemas dan Depresi. Cetakan Keempat, Ed. Kedua, Jakarta: FKUI.

Kalarhoudi A (2011). Assessment of Quality of Life in Menopausal Periods: A Population Study in Kashan, Iran. Iranian Red Crescent Medical Journal. 13(11):811-817.

Kemenkes RI (2015). Profil Kesehatan Indonesia Tahun 2014. Jakarta: Kemenkes RI, ISBN: 978-602-2359111.

Kothiyal P, Monika S (2013). Post menopausal quality of life and associated factors-A Review. Journal of Scientific and Innovative Research, 2(4): 814823.

Luoto R (2009). Hot flushes and quality of life during menopause. BMC Women's Health, 9:13.

Lubis N, Hasnida (2009). Dukungan Sosial pada Pasien Kanker Perlukah?. Medan: USU Press.

Murti B (2013). Desain dan Ukuran Sampel untuk Penelitian Kuantitatif dan Kualitatif di Bidang Kesehatan. Yogyakarta: Gajah Mada University Press.

Profil Kesehatan Kabupaten Kediri Tahun 2014. (2014). Diakses dari http: //www.depkes.go.id/resources/downl oad/profil/PROFIL_KAB_KOTA_201 4/3506_Jatim_Kab_Kediri_2014.pdf

Seeta D, Sheela U, Ranjana C, Sheetal B (2015). Assessment of Menopausal Symptoms Using Modified Menopause Rating Scale (MRS) Among Middle Age Women in Selected 
Journal of Maternal and Child Health (2017), 2(2): 125-136

https://doi.org/10.26911/thejmch.2017.02.02.04

Urban And Rural Area Of Pune District. Journal Of Advanced Scientific Research 2015, 6(3): 47-50, ISSN 0976-9595.

Senba N, Matsuo H (2010). Effects of a health education program on climacteric women. Climacteric. 2010; 13: 561-569

Sudeshna R, Aparajita D (2012). An assessment of QOL and its determining factors of post menopausal women in a rural area of West Bengal, India: A multivariate analysis. International Journal of Medicine and Public Health, 2(4).
Tamai SB, Paschoal SMP, Litvoc J, Machodo AN, Curiati PK, Prada L (2006). Impact of a program to promote health and quality of life of elderly. Einstein.

Trisetiyaningsih Y (2016). Hubungan gejala menopause dengan kualitas hidup perempuan klimakterik. Jurnal Kesehatan "Samodra Ilmu", 7(1).

Yanuarty M (2014). Hubungan Antara Faktor Risiko Osteoartritis Lutut dengan nyeri, Disabilitas, Dan Berat Ringannya osteoartritis. eprints.undip.ac.id/44826/3/ Diakses 5 Mei 2017. 